\title{
Quality Assurance Practice in African Universities: Lessons from a Private Nigerian University \\ Jonathan Adedayo Odukoya
}

adedayo.odukoya@covenantuniversity.edu.ng

\section{Shalom Nwodo Chinedu}

shalom.chinedu@covenantuniversity.edu.ng

Tayo 0. George

tayo.george@covenantuniversity.edu.ng

Elizabeth Olowookere

elizabeth.olowookere@covenantuniversity.edu.ng

Godwyns Agbude

godwyns.agbude@covenantuniversity.edu.ng

\section{Doi:10.5901/jesr.2015.v5n2p251}

Abstract

\begin{abstract}
The education enterprise and indeed businesses worldwide thrive on quality products and services. It can be posited that the success or survival of any enterprise is strongly contingent on the quality of its business processes and products. Information explosion and global competiveness have placed a compelling demand on educational institutions to enhance the quality of their delivery process and products. These clarion statements serve to justify the need for this study. The core research questions addressed are: What are the quality assurance models operational in the Nigerian private university studied? To what extent do the models meet international standard? How are the Quality Assurance models implemented? What are the challenges experienced in the course of implementing the Quality Assurance models? What is the degree of overall success in attaining and maintaining quality? The ex post facto, case study and survey designs were used in this study. Consequently, questionnaires, interview guideline and observation grids were among the instruments used for data collection. Data was analyzed with simple descriptive statistics and qualitative techniques. Some of the Quality Assurances practices/models adopted in the private Nigerian University were: National University Commission [NUC] Accreditation visits; Proprietor's impromptu visits; Faculty Support Programme; Webometric Ranking Model, and Thomas Reuter University Ranking Model. Findings reveal that though Quality Management practice in the Nigerian private university studied was of world-class standard, there is still room for improvement.
\end{abstract}

Keywords: Quality Assurance, Evaluation, Tertiary Institution, Growth and Development

\section{Introduction}

It can be posited that people buy quality. Take the automobile world for instance, Toyota, Honda and Nissan are leaders in this business field today largely because they have learnt to attain and maintain quality of their product and service. They listen to their customers and strive for continuous quality improvement in line with their expectations per time. For business survival, it is imperative that an organization learn to attain and maintain quality. It is the significance of this concept that inspired this study.

The issue of quality at the tertiary level of education is receiving greater attention in sub-Saharan Africa (SSA). The apparent reason for this development is the proliferation of private universities and the attendant dwindling quality service delivery. According to Materu (2007), government officials from countries like Ethiopia, Madagascar, South Africa 
and Nigeria have expressed the need to improve quality of tertiary institutions [private and public], and the need to ensure that tertiary education services meet acceptable international standards.

The main purpose of Quality Assurance [QA] agencies in many SSA countries seems to be for licensing and regulation rather than for quality improvement. The mandate of existing national QA agencies tends to differ from country to country. In some countries, the Minister of Education authorizes the licensing of higher institutions. In other countries like Nigeria, the QA assignment spans comprehensive, system-wide program accreditation and ranking of institutions. Ironically, the accreditation exercise tends to be private institutions. Hardly were public universities subjected to full institutional accreditation process.

The private university studied in this research exercise commenced operations in 2002 and recently announced the compelling vision of becoming one of the best ten universities in the world by 2022. The vision is tagged 'Vision 102022' or 'one of ten in ten (1-10-10)'. It is a vision that calls for continuous total quality control. This study therefore investigated the degree of quality control in one of the leading private universities in Nigeria.

There is growing complaints by employers that university graduates are poorly prepared for the world of works (Ansu in Moteru, 2007). The concern is further accentuated with the proliferation of private universities in many African countries in recent times. With population explosion all across the globe, the attendant enrolment increase in virtually all tertiary institutions and the incommensurate infrastructural development, the concern for quality seems more justified.

Every organization, including educational institutions, thrive on the platform of quality. Quality is a multidimensional concept embracing universities' functions and activities such as student admission, promotion and certification process, staff recruitment and promotion, curriculum development, teaching, learning, research, infrastructural development, equipments, community development and related issues. According to Giertz (2000), without quality, there is hardly a university in the full sense of the word. Refusal to make astute regular quality assurance inspections and corrections are apt to deplete the quality of operations in an organization. This study is intended to serve as wake-up call to African tertiary institutions, with the intention of catalyzing the attainment and maintenance of quality operations in these institutions. For this reason, this study is quite significant.

In this study, quality is equated with maintenance of internationally acceptable standard of evolving a product or service, such that the recipients of such service/product enjoy commensurate value for money paid. The entire process of ensuring the delivery of such quality service is tagged Quality Assurance [QA] or Quality Control [QC]. Quality culture is the stable or enduring QA practices in an organization that has virtually become a way of life for the staff and proprietors of such organization.

As it operates in accounting audit system, quality assurance may be internal or external (Njoku, 2006). External quality assurance refers to the role of an external body, like the National University Commission [NUC] in Nigeria, which assesses the university operations and/or its programmes to determine if it is meeting the set standards. Internal quality assurance on the other hand refers to a university's programmes and mechanisms for ensuring quality. In the university under study, the internal quality control system was handled by the Central Quality Control Unit.

As organizations tried to find ways of reducing the number of defects in their products and services, more complex quality control mechanisms were developed. "Quality assurance", therefore, came out of attempts to prevent defects from occurring, rather than solely focusing on finished products. Today, systems and strategies have been developed to monitor quality at all stages of production. The emphasis is more on 'prevention' than 'cure'. The latter appears to be the emphasis of "Total quality management - TQM". TQM examines virtually all the steps of production.

\subsection{Traditional ways of monitoring and improving quality in Education}

From the inception of time, a number of traditional ways have been established to monitor and ensure continuous improvement in the quality of education in Africa. For instance, in the West African sub-region, particularly in Nigeria, Liberia, the Gambia, Sierra Leone and Ghana, the quality of secondary education has been externally handled by the West African Examinations Council [WAEC]. The WAEC was thus solely responsible for conducting external examinations for certification purposes. The respective schools have their various internal examinations for the purpose of assuring internal quality.

Another traditional way of assuring quality in education is through International tests such as the International General Certificate of Secondary Education [IGCSE] conducted by the Cambridge Examination Syndicate and the Scholastic Aptitude Test [SAT] conducted by the Education Testing Service [ETS], Princeton, NJ.

Inspections by Education Boards and screenings by Professional Associations are other traditional quality control practices that have been in vogue for years. Inspection has been associated with schools. Traditionally, it has been 
used to monitor the quality of teaching, learning and testing, and other aspects of schools. Such School Inspectors provide feedback to government about the levels of educational quality in schools. A number of careers have professional associations which serve to maintain standards of training and practice within their respective professions. These bodies at times serve as licensing institutions and offer specialized courses to enhance the quality of their members.

\subsection{Statement of Objectives}

The core objectives of this study are to find out the

1. quality assurance models operational in the private Nigerian university

2. extent to which the models meet international standard?

3. challenges experienced in the course of implementing the Quality Assurance models in the private Nigerian university

4. degree of awareness of quality control by Students in the private Nigerian university

5. degree of awareness of quality control by Lecturers in the private Nigerian university

6. impact of quality assurance drive in the private Nigerian university

7. degree of overall success in attaining and maintaining quality in the private Nigerian university.

\subsection{Research Questions}

1. What are the quality assurance models operational in the private Nigerian university?

2. To what extent do the models meet international standard?

3. What are the challenges experienced in the course of implementing the Quality Assurance models in the private Nigerian university?

4. What is the degree of awareness of quality control by Students in the private Nigerian university?

5. What is the degree of awareness of quality control by Lecturers in the private Nigerian university?

6. What is the impact of quality assurance drive in the private Nigerian university?

7. What is the degree of overall success in attaining and maintaining quality in the private Nigerian university?

\section{Method}

The ex post facto, case study and survey designs were used in this study. These are in tandem with the set objectives. As a case study project, the primary focus was not on population and sample. The focus of study was not on human entity but rather on activities and structures within the university that make for the overall quality delivery. This point nonetheless, information on the quality of these activities were obtained from management, staff and students of the case study institution. The core instrument used for this study was the Quality Assurance Interview Guideline [QAIG] and Quality Assurance Observation Guideline [QAOG]. The QAIG contained the a brief introductory section; a section on degree of awareness of the quality assurance practices in the university; Common challenges experienced in the course of implementing Quality Assurance at CU and Degree of Success in Attaining and Maintaining Quality; strategies for implementing the quality assurance models and suggestions for improvement. The QAOG followed the same format.

The content validity was ascertained via expert judgment. Data was collected by interviewing students, lecturers and Management using the QAIG. Data collected was analyzed with simple descriptive statistics of frequency count and percentage. Qualitative analysis was also applied on some of the data. 


\section{Results}

\subsection{Students' Who Were not Aware of Quality Control Practices in a Private Nigerian University}

Table 1: Students' Who Were not Aware of Quality Control Practices in a Private Nigerian University

\begin{tabular}{|l|c|c|c|c|c|c|c|}
\hline \multicolumn{1}{|c|}{$\begin{array}{c}\text { Students' Interview [N=48] } \\
\text { Not Aware }\end{array}$} & $\begin{array}{c}\text { Quality } \\
\text { Assurance } \\
\text { Team's } \\
\text { Inspection }\end{array}$ & $\begin{array}{c}\text { HOD } \\
\text { Inspectio } \\
\mathbf{n}\end{array}$ & $\begin{array}{c}\text { Deans } \\
\text { inspection }\end{array}$ & $\begin{array}{c}\text { University } \\
\text { Management } \\
\text { Inspection }\end{array}$ & $\begin{array}{c}\text { NUC impromptu } \\
\text { Inspection }\end{array}$ & $\begin{array}{c}\text { Proprietor's } \\
\text { impromptu } \\
\text { Inspection }\end{array}$ & $\begin{array}{c}\text { CCTV } \\
\text { Recording } \\
\text { s }\end{array}$ \\
\hline Lecture Delivery & $44[92 \%]$ & $39[81 \%]$ & $41[85 \%]$ & $39[81 \%]$ & $44[92 \%]$ & $44[92 \%]$ & $28[58 \%]$ \\
\hline Exam Conduct & $21[44 \%]$ & $39[81 \%]$ & $46[96 \%]$ & $35[73 \%]$ & $48[100 \%]$ & $48[100 \%]$ & $48[100 \%]$ \\
\hline Result Processing & $48[100 \%]$ & $37[77 \%]$ & $47[98 \%]$ & $33[69 \%]$ & $48[100 \%]$ & $48[100 \%]$ & NA \\
\hline Departmental Management & $\mathrm{NA}$ & $42[88 \%]$ & $44[92 \%]$ & $37[77 \%]$ & $45[94 \%]$ & $\mathrm{NA}$ & $\mathrm{NA}$ \\
\hline University Management & $46[96 \%]$ & $47[98 \%]$ & $47[98 \%]$ & $40[83 \%]$ & $41[85 \%]$ & $45[94 \%]$ & $47[98 \%]$ \\
\hline Hostel Management & $43[90 \%]$ & $\mathrm{NA}$ & $40[83 \%]$ & $43[90 \%]$ & $47[98 \%]$ & $47[98 \%]$ & $\mathrm{NA}$ \\
\hline Cafeteria Management & $45[94 \%]$ & $\mathrm{NA}$ & $44[92 \%]$ & $41[85 \%]$ & $46[96 \%]$ & $\mathrm{NA}$ & $\mathrm{NA}$ \\
\hline Clinic Management & $45[94 \%]$ & $47[98 \%]$ & $45[94 \%]$ & $40[83 \%]$ & $46[96 \%]$ & $47[98 \%]$ & $\mathrm{NA}$ \\
\hline Library Management & $44[92 \%]$ & $47[98 \%]$ & $44[92 \%]$ & $42[88 \%]$ & $44[92 \%]$ & $\mathrm{NA}$ & $\mathrm{NA}$ \\
\hline Computer System & $46[96 \%]$ & $\mathrm{NA}$ & $\mathrm{NA}$ & $45[94 \%]$ & $\mathrm{NA}$ & $47[98 \%]$ & $43[90 \%]$ \\
\hline Infrastructural System Management & $44[92 \%]$ & $47[98 \%]$ & $47[98 \%]$ & $36[75 \%]$ & $\mathrm{NA}$ & $46[96 \%]$ & $\mathrm{NA}$ \\
\hline Capacity Building & $46[96 \%]$ & $46[96 \%]$ & $46[96 \%]$ & $47[98 \%]$ & $47[98 \%]$ & $47[98 \%]$ & $\mathrm{NA}$ \\
\hline Research & $43[90 \%]$ & $\mathrm{NA}$ & $\mathrm{NA}$ & $42[88 \%]$ & $\mathrm{NA}$ & $\mathrm{NA}$ & \\
\hline Productivity & $43[90 \%]$ & $46[96 \%]$ & $45[94 \%]$ & $42[88 \%]$ & $47[98 \%]$ & $\mathrm{NA}$ & $\mathrm{NA}$ \\
\hline
\end{tabular}

Key: NA = Not Applicable; the Percentages represent those who were not aware or felt the observed practice were barely effective. .

Source: Field work

The general trend revealed in this result is that majority of the students interviewed were not aware of any quality assurance practice or reported that the observed quality assurance practice in this private university were barely effective. This ranged from $44 \%$ to $100 \%$ Except once, this figure was well above $50 \%$ in all cases and many were in the range of $90 \%-100 \%$.

\subsection{Lecturers' Awareness of Quality Control Practices in a Private Nigerian University}

Table 2: Lecturers' Awareness of Quality Control Practices in a Private Nigerian University. Other international modes of quality control are: Webometric ranking team and Thomson Reuter University Ranking Team.

\begin{tabular}{|c|c|c|c|c|c|c|c|}
\hline $\begin{array}{l}\text { Summary of } \\
\text { Lecturers' Views }\end{array}$ & $\begin{array}{l}\text { Quality Assurance } \\
\text { Team's Inspection }\end{array}$ & $\begin{array}{c}\text { HOD } \\
\text { Inspection }\end{array}$ & $\begin{array}{l}\text { Deans } \\
\text { inspection }\end{array}$ & $\begin{array}{c}\text { University } \\
\text { Management } \\
\text { Inspection }\end{array}$ & $\begin{array}{c}\text { NUC } \\
\text { impromptu } \\
\text { Inspection }\end{array}$ & $\begin{array}{l}\text { Proprietor's } \\
\text { impromptu } \\
\text { Inspection }\end{array}$ & $\begin{array}{c}\text { CCTV } \\
\text { Recordings }\end{array}$ \\
\hline Lecture Delivery & Started this Semester $[E]$ & Not Aware & Partial [NE] & Partial [NE] & Not Aware & Not Aware & Not Aware \\
\hline Exam Conduct & Done [Effective] & $\begin{array}{c}\text { Done } \\
\text { [Effective] }\end{array}$ & $\begin{array}{c}\text { Done } \\
\text { [Effective] }\end{array}$ & Done [Effective] & Not Aware & Not Aware & Not Aware \\
\hline Result Processing & Not Aware & $\begin{array}{c}\text { Done [Fairly } \\
\text { Effective] }\end{array}$ & $\begin{array}{c}\text { Done [Fairly } \\
\text { Effective] }\end{array}$ & Done [Fairly Effective] & Not Aware & Not Aware & Not Applicable \\
\hline \begin{tabular}{|l|} 
Departmental \\
Management
\end{tabular} & Not Aware & $\begin{array}{c}\text { Not } \\
\text { Applicable }\end{array}$ & $\begin{array}{c}\text { Partial [Started } \\
\text { in a College] }\end{array}$ & Done [Fairly Effective] & Not Aware & Not Aware & Not Applicable \\
\hline $\begin{array}{l}\text { University } \\
\text { Management }\end{array}$ & Not Applicable & $\begin{array}{c}\text { Not } \\
\text { Applicable }\end{array}$ & Not Applicable & Not Applicable & Not Aware & Done & Not Applicable \\
\hline Hostel Management & Not Aware & Not Aware & Done by DSA & Done [Fairly Effective] & Not Aware & Not Aware & Partial \\
\hline \begin{tabular}{|l|} 
Cafeteria \\
Management
\end{tabular} & Not Aware & Not Aware & Done by DSA & Done [Fairly Effective] & Not Aware & Not Aware & Not Aware \\
\hline Clinic Management & Not Aware & Not Aware & Done by DSA & Done [Fairly Effective] & Not Aware & Done & Not Aware \\
\hline \begin{tabular}{|l|} 
Library \\
Management
\end{tabular} & Not Aware & Not Aware & Not Applicable & Done [Fairly Effective] & Not Aware & Not Aware & Done $[E]$ \\
\hline Computer System & Partial [Fairly Effective] & Not Aware & Not Applicable & Done [Fairly Effective] & Not Aware & Not Aware & Done [E] \\
\hline $\begin{array}{l}\text { Infrastructural } \\
\text { System } \\
\text { Management }\end{array}$ & Not Aware & Not Aware & Not Aware & Done [Fairly Effective] & Not Aware & Done & Done \\
\hline Capacity Building & Not Aware & Not Aware & Not Aware & Done [Fairly Effective] & Not Aware & Done [Spiritual] & Not Applicable \\
\hline Research & Not Aware & Not Aware & Not Aware & Done [Effective] & Not Aware & Not Aware & Not Applicable \\
\hline Productivity & Not Aware & Not Aware & Not Aware & Done [Fairly Effective] & Not Aware & Not Aware & Not Applicable \\
\hline
\end{tabular}

Source: Field work

Table 2 shows that virtually all Lecturers were aware of Management's quality assurance drives in all the units/sections 
listed. They were equally aware of the Dean of Students' affairs effort at quality assurance in the hostel, cafeteria and Clinic. Lecturers were also aware of the Proprietor's drive in ensuring quality practice in the areas of security, clinic, management and infrastructure development and maintenance. They further reported increasing number of CCTV at strategic location on the campus, all in the bid to assure quality. Heads of department were only confirmed to contribute to close monitoring and quality assurance during the conduct of examinations and result processing, The same applies to the Dean of Student Affairs. Lecturers were not aware that the National University Commission [NUC] ever made impromptu checks on the university for quality control. However, even though the University Management were seen to actively drive quality control in almost all sectors of the university, Lecturers felt such efforts were only fairly effective.

\subsection{Findings from the University Management Representative}

\subsubsection{Purpose of Quality Assurance}

Quality assurance is imperative for the University to:

(a) Deliver on its basic functions (teaching, research, innovation and community service).

(b) Ensure effective service delivery (which demands that facilities and accompaniments must be quality-defining and quality-driven).

(c) Enhance its rating, locally and globally (Institutional/Programme accreditation and University ranking are based on similar measurable indices that are quality-defined).

(d) Provide solutions to national and global needs.

(e) Meet the expectations of its students and their parents/guardians.

(f) Achieve the set goals of its proprietors.

\subsubsection{What are the quality assurance models operational in Covenant University?}

(a) Team work - everyone, from professor to the cleaner, is involved.

(b) Bottom up - Starts from the Unit/Departments to the whole University.

(c) Internal quality assurance - Emphasis is on internal assurance mechanisms.

(d) Continuous quality improvement is the focus. We are not there yet!

(e) The external quality assurance is a mere validation of the efficiency of the internal assurance mechanisms.

\subsubsection{To what extent do the models meet international standard?}

(a) The model is dynamic.

(b) It pays attention to the international trend while ensuring adherence with the national regulatory mechanisms.

(c) The National University Commission [NUC] Benchmark Minimum Academic Standards (BMAS) of 2007 enunciates the learning outcomes and competences expected of graduates of each academic programme.

(d) The NUC has established a regular pattern of accreditation of academic programmes in all Universities regardless of proprietorship.

(e) Our programmes are accredited by both the NUC and the relevant professional bodies such as COREN, ICAN, etc.

\subsubsection{How are the Quality Assurance models implemented?}

(a) Quality Assurance and Academic Standards Unit:

The Quality Assurance and Academic Standards (QAAS) unit was established as the fulcrum of the University's quality system management and enhancement:

- To drive the University's quality and academic standards imperatives;

- To ensure continuous quality improvement and entrench the culture of excellence and best practices in all facets of the University's operations;

- To supervise and coordinate the University's internal quality assurance and

- To prepare the Institution/Programmes for external quality assurance visits, in conjunction with the Academic Planning unit (APU). 
(b) Quality and Academic Standards Committees:

The Quality and Academic Standards Committees perform advisory, supervisory and oversight functions at their different levels of operation.

The Committees include:

- Central Quality and Academic Standards Committee

- College Quality and Academic Standards Committee

- School Quality and Academic Standards Committee

- Departmental/Unit Quality and Academic Standards Committee

\subsubsection{What are the challenges experienced in the course of implementing the Quality Assurance models?}

- Adequate funding - Huge investment is needed to acquire/upgrade teaching and learning facilities to meet international standards, particularly, the laboratories, workshops, studios, libraries, etc.

- Personnel - Attracting and retaining high qualified world-class scholars is a challenge.

- Students - there is also a challenge of attracting the best local and international students.

\subsubsection{What is the degree of overall success in attaining and maintaining quality in Covenant University?}

- To a very high degree, there is room for improvement.

- It shows in the staff and students, curriculum, available resources, and facilities.

- All undergraduate and postgraduate programmes have full accreditation status of both the NUC and their professional bodies.

- The University is highly rated amongst her contemporaries.

- The quality of her graduates is very commendable. They have competitive edge over their peers and are rated among the best in the world.

\subsection{Findings from Lecturers, Students and Researchers' Observations}

\subsubsection{What are the quality assurance models operational in the private Nigerian University studied?}

\subsubsection{The Faculty [i.e. Lecturers] in their observations acknowledged the following QA models in the University:}

1. National University Commission [NUC] Accreditation visits

2. Proprietor's impromptu visits and close monitoring of Management's implementation of Annual/Semester Strategic Plans and relevant book of records.

\subsubsection{Students' Observations}

Majority of the students interviewed were not aware of the quality assurance models operational in the university.

\subsubsection{Researchers' Observations}

1. All the models indicated above

2. The Faculty Support Programmes (FSP) - to add value to students living and learning contexts outside the classroom.

3. Webometric Ranking Model

4. Thomas Reuter University Ranking Model

\subsubsection{To what extent do the models meet international standard?}

From the researchers' observation, coupled with information from literature review, the following internal quality assurance models that meet international standard were implemented in the private Nigerian university studied:

Policy and procedures for quality assurance: The target Institution have a policy for the assurance of the quality 
and standards of its programmes; Approval, monitoring and periodic review of programmes and awards: The target institution have formal mechanisms for the approval and periodic monitoring of its programmes; Assessment of students: Students were assessed using published criteria which are applied without bias; Quality assurance of teaching staff: The target institution conducts regular quality assurance inspections of Lecturers in the classroom whilst encouraging students to evaluate their lecturers on teaching competence once every semester. The university offers regular feedback to Lecturers on the outcome of these evaluations; Learning resources and student support: To a large extent, the target institution ensured that relevant state of the art teaching and learning resources for all programmes offered were available for the support of student learning; Information systems: Relevant information for the effective management of programmes of study and other activities were collected, analysed and fairly use; Public information - The target institution regularly published up to date, objective information about the programmes and awards offered.

3.4.3 What are the challenges experienced in implementing the Quality Assurance models in the private Nigerian university studied?

Observations and interviews revealed the following challenges:

1. The quality assurance teams were often opposed by Lecturers in the course of discharge of their duties. It was observed that mere sighting of the quality assurance team in the classroom make some Lecturers uncomfortable.

2. Management barely use the feedback from the quality assurance efforts

3. Relevant equipment and materials for effective QA were lacking in the university. Example is CCTV in lecture halls linked with top management officers.

3.4.4 What is the degree of awareness and impact of quality control by Students in the private Nigerian university studied?

Majority of the students interviewed were not aware of the quality assurance practices in the institution. The few who were aware felt such practices were not effective enough.

\subsubsection{What is the degree of awareness and impact of quality control by Lecturers in the private Nigerian university studied?}

Majority of the Lecturers interviewed were only aware of the NUC accreditation visits and Management's occasional quality assurance drives, such as VC's visit to departments to collect evidences of publications, inspections of University Management team during semester examinations and obtaining feedback from HODs during monthly Management meetings and via HODs reports. Even then, the Lecturers felt many of these QA drives were not effective enough.

\subsubsection{What is the degree of overall success in attaining and maintaining quality in the private Nigerian university studied?}

From majority of the respondents interviewed and from the Researchers' observations, quality maintenance in the areas of infrastructural facilities tend to be optimal, though there is room for improvement. However, in the areas of teaching, learning, testing and library resources, the finding was that the QA standard was good. However, for the hostel, clinic, cafeteria, sporting and related facilities the QA was perceived as substandard. Management need to beef up quality assurance practices in these areas to meet international standard.

\section{Discussion and Recommendation}

Going by the international quality control standard submitted by the European Association for Quality Assurance in Higher Education (2009), it is quite apparent that the private Nigerian university studied met more than $60 \%$ of the required internal quality assurance models. However, as observed by the Researchers and most of the Lecturers who participated in this study, there is room for improvement. Some of the areas that need improvement are enumerated below.

The programme curricula and course compacts need more intensive and regular review to meet national needs 
and international standards. More effort should also be made to standardize Students' assessment in terms of test development, validation, administration, scoring, grading and interpretation. This statement covers both formative [i.e. continuous assessments] and summative assessments. The assessment issue should also be extended to the post University Matriculation Examination [UME] screening exercise. This is the genesis of quality control.

In the area of learning resources, the management of the private Nigerian university studied need to pay more attention to provision of basic technological infrastructures that will facilitate inventions, productivity and development. This is particularly more relevant in the science, technology and engineering disciplines. The functionality of the acquired gadgets should be maintained.

While relevant information for the effective management of programmes of study and other activities were often collected and analysed, there is however need for management to make more concerted effort to utilize such information to effect pragmatic reforms. Collation of information should be extended to stakeholders outside the university. Parents for instance should be more involved. Students should also be more informed and engaged in the quality control drive.

An area worthy of commendation is the application of external quality assurance models. From current empirical literatures on this subject [e.g. Materu, 2007], the following robust external quality assurance [QA] models were identified: Affiliation Model; External Examiner Model; Professional Association QA Model; National Quality Assurance Agency Model; National University Ranking Model; Regional QA Model [e.g. Conseil Africain et Malgasche pour l'Ensignement Supérieur (CAMES), Southern African Development Community (SADC), the Association of African Universities (AAU) Quality Assurance Initiative etc] and International QA Models [e.g. Thompson Reuter World University Ranking, Webometric Ranking etc]. The private Nigerian university fully subscribed to virtually all the listed external quality assurance models except the affiliation model. The closest to this is the Collaborative model with numerous MoUs signed with top ranking universities from developed nations. There is no doubt the university has passed the stage of affiliation. However, the university management should not allow the foreign parameters that often neglect local needs, to wholly determine the spate of activities in the institution. More concerted effort should be made to solve pressing community and national needs such as poverty, security challenges [such as Boko Haram killings, armed robbery, political killings, ritual killings etc], poor governance, lack of consistent and affordable electricity, lack of pipe borne water, poor roads, to mention but few. There is hardly any institution that is community relevant that will not ultimately become world renowned.

\section{Conclusion}

This study has shown that there is hope for higher education in Africa. With the advent of private universities in Africa the growing concern has been that of quality. This led to the enhanced legal empowerment of the National University Commission and similar Quality Control agencies in Africa. However, given the one-shot accreditation strategy of this agency, world class quality assurance standard could hardly be attained and maintained. There is dire need for the respective higher education institutions to engage in concerted internal quality assurance practices. It is the latter practice that will actually deliver the much desired quality. It is interesting to note the Nigerian private university selected for this study is barely 12 year old, yet it has accomplished to much in terms of quality control, so much that it is already entering the rank of best 10 at national, regional and continental levels. This is unique for a private African university where only few expect any good thing to evolve. It is not just about ranking, the quality of the primary products of this institution [students] is a clarion proof of this assertion. Of-course, the institution is not yet there. There is clearly room for improvement and recommendations have been offered in these areas. There is no doubt that as this and similar institutions adopt this world class standard of quality assurance, African states and their citizens will experience a better standard of living.

\section{References}

Ansu Yaw in Materu, Peter (2007). Higher Education Quality Assurance in Sub-Saharan Africa: Status, Challenges, Opportunities, and Promising Practices [Foreword]. World Bank Working Paper No.124.Washington: African Region Human Development Department, World Bank

European Association for Quality Assurance in Higher Education (2009). ENQA report on Standards and Guidelines for Quality Assurance in the European Higher Education Area - 3rd edition. Helsinki: European Network for Quality Assurance in Higher Education (ENQA)

Glertz, B (2000). "The Quality Concept in Higher Education". Uppsala: Upsala University, Development and Evaluation Unit.

Harvey, L; and Green, D, (1993) Defining quality, assessment and evaluation Higher Education; An International Journal, 18, No.1. 
International Institute for Educational Planning (IIEP) (2006), Making Basic Choices for External Quality Assurance Module 1, External Quality Assurance;Options for Higher Education Managers, Paris; UNESCO.

Materu, Peter (2007). "Higher Education Quality Assurance in Sub-Saharan Africa: Status, Challenges, Opportunities, and Promising Practices". World Bank Working Paper No.124.Washington: African Region Human Development Department, World Bank

Njoku, Placid (2006) Quality Imperatives and World Class Standards: positioning Universities in Africa for the Twenty-First Century Convocation Lecture presented at the First Convocation Ceremony of Covenant University.

Van Ginkel J.A. and Dias, M.A.R. (2007), Institutional and political challenges of accreditation at the international level. In Higher Education in the World 2007: Accreditation for Quality Assurance: What is at stake? New York: Palgrave and GUNI. 
